\title{
State Making and State Craft: A Critical Review of the Misconception of Amalgamation of Nigeria In 1914
}

\author{
${ }^{1}$ Yakubu Haruna Jae, ${ }^{2}$ Ntim Gyakari Esew \\ ${ }^{I}$ Department of Political Science, Kaduna State University, Kaduna \\ ${ }^{2}$ Department of Political Science, Kaduna State University, Kaduna.
}

\begin{abstract}
This paper examines the false perception attached to the amalgamation of Nigeria in 1914. The research reviewed and falsified two fundamental historical fallacies which assumed that the various ethnic groups and parts or regions of Nigeria were in perpetual antagonism before that historic amalgamation. And that the essence of British integration was for unification. The research after a thorough investigation and consultation of relevant literatures, established that, the prime objective of British amalgamation was the desire to achieve a total and effective control over Nigeria. For the British to achieve this mission, they used both military and non-military approaches. The paper finally recommends that since the amalgamation had taken place, Nigerian leaders should not abuse it but rather consolidate it. Unity, peace and harmony, tolerance and equality should be strengthened.
\end{abstract}

Key words: Amalgamation, North, South, Unification, and Integration

\section{Introduction:}

It is a mistake for somebody to say that Nigeria came into being in 1914, because one has to look at how the various parts [North, West and East] came into being. The country today known as Nigeria went under series of amalgamations in the East, West and North before the final one in 1914. Unless we are clear about Nigeria's history chronologically we cannot understand how Nigeria came into being and how the current states were created.

It is incorrect for somebody to say that there were nations and kingdoms independent of each other before the coming of the British colonialists, but the truth of there were interactions among them like trading before the formal coming of the British powers and people did not consider others as settlers or outsiders as rightly observed by (Siddique, 2009).

The history of the amalgamation of Nigeria in 1914 has been twisted, and distorted by many people. It is sometimes attached with myths as Bala and Al-kasim (1991) (Afigbo, 2003) noted in their book Bala \& Alkasim, (2000) Misrepresentation of Nigeria by Nigerians which was corroborated by Afigbo (2003) Maintain that the formation of Nigeria was misunderstood, in that some people believed that the Federal Republic of Nigeria is an amalgam of two distinct geographical, cultural, economic, social and political entities namely the North and the South. These distinct entities, according to this conception have been, brought together by the British for their own reasons i.e the 1914 amalgamation of the colony and protectorate of southern Nigeria and the protectorate of Northern Nigeria

However, it should be noted that according to this conception these two amalgamated entities have never been fused or merged into one, but have remained an amalgam of two distinct, and often antagonistic entities in terms of their background, interests, and aspirations (Bala and Alkasim, 2000), (Afigbo,2003) all disputed this conceptions .

\section{Background of Nigeria}

Nigeria's official name is Federal Republic of Nigeria and has a total land area of $923,768 \mathrm{sq}$, with a climate annual rain fall ranging from $381 \mathrm{~cm}$ along the coast and $64 \mathrm{~cm}$ or less in the far North. Nigeria has a population of about $157,000,000$ according to 2006 population census. It was colonized by the British the North and South were amalgamated for political reasons in 1914 by them and she became independent on $1^{\text {st }}$ October, 1960. Nigeria, geographically, is located in West Africa, bounded in the North by Niger Republic, in the East by Cameroon Republic, in the West by Benin Republic and in the North - East by Chad Republic, Nigeria is the fourth largest country in West Africa.

\section{Nigeria Before The Amalgamation Of 1914}

As noted earlier, there were contacts and trade relations among various ethnic groups and communities in what is called Nigeria before the coming of British rule. This paper argues that it is fallacious for somebody to say that the various ethnic groups and various parts of Nigeria were in perpetual antagonism before the 
amalgamation and that that reason alone made the British colonialist to bring them together for unification or integration (i.e amalgamation).

By 1900, Nigeria had come to be recognized by other colonial powers as a British colony. This was as a result of the Berlin Conference of 1885 which partitioned the whole of Africa including Nigeria which was geographically given to the British imperialists. By 1900 the desire to achieve a total and effective control over Nigeria constituted the prime objective of the British colonial administrators in the early phase of their rule which lasted from 1900 to 1914 (Falola, Mahadi, Anyanwu, Uhomoibhi, 1991). To achieve this, the colonial authorities used both violent and non-violent means.

\section{The Amalgamation Of 1914}

In the words of Lord Lugard when he was narrating how the amalgamation of 1914 came into been he said:

Towards the close of 1911, Mr Harcurt, Secretary of State for the Colonies, invited me to undertake the task. I was at the time Governor of Honk Kong, having previously been High Commissioner of Northern Nigeria from its inauguration in 1900. I was therefore intimately acquainted with the method of administration there, for the creation of which I had indeed been responsible. Reaching England in April, 1912, I was appointed Governor of the two separate administrations simultaneously, and after spending several weeks in England, to acquaint myself with the current views on some important matters, I proceeded to Africa in September, 1912. I returned in the following March, and submitted my proposals for amalgamation in May. They were accepted in September, when I returned to Nigeria, and in January $1^{\text {st }} 1914$, the new Government of Nigeria as set up by fresh letters patent and other instruments, was proclaimed. (Lord Lugard quoted from Kirk-Greene)

Simply put, Amalgamation here means the policy of the British (under Lord Lugard) to amalgamate (integrate) the various parts of Nigeria ( North, East, West) into one unit for proper control of the area. It is a measure taken by Britain to strengthen her rule in the early phase of her administration. Falola, Mahadi, Anyanwu, Uhomoibhi (1991) define amalgamation as the bringing together of the various Nigerian People under one administrative and political authority.

By 1900, there were three separate independent territories all under British administration in Nigeria, these three territories were; the Niger Coast Protectorate (created in 1891 as the oil Rivers Protectorate) the Lagos Colony which was formed in 1861 and the Territory of the Royal Niger Company (now Northern Nigeria). How to bring all these territories under one Administrative and political authority was given attention by British officials even before 1900 (Falola, Mahadi, Anyanwu, Uhomoibhi, 1991). Joseph Chamberlion, the then British Colonial Secretary in 1898 set up a Committee on the future administration of the Royal Niger Company's Territory. The Committee recommended for the bringing together of the different governments into one Nigeria. This ultimately led to the appointment of Lord Lugard as the Governor General of Nigeria. Lord Lugard showed interest in amalgamating the three regions known as the "three Nigeria" which later became really implemented in 1914 (Falola, Mahadi, Anyanwu, Uhomoibhi, 1991). From the foregoing we can, therefore, acknowledge that from 1898 the British decided to amalgamate the various administrative units of the country.

Interestingly, we shall note that before the amalgamation of 1914, the various parts of Nigeria went under series of amalgamations by colonial powers. This means that the amalgamation of the North and South in 1914 did not take place at once, it was a gradual process. All the "three Nigeria "went under series of Amalgamations before 1914, (Siddique,and Dunmoye 2009)

In 1893, for example according to Bala and Alkassim, (2000) The Oil Rivers Protectorate was amalgamated with other Territories nearby, which the British had subjugated, to form the Niger Coast Protectorate. This Niger Coast Protectorate, which only in 1897, came to include the conquered Kingdom of Benin, for example was conquered in 1900, amalgamated with a series of Protectorates, the British had imposed in the immediate hinterland of the Colony of Lagos to form the Protectorate of Southern Nigeria, administered separately from the Colony of Lagos. Six years later, as noted by Bala and Alkassum(2000), in 1906, the colony of Lagos was amalgamated with this Protectorate of Southern Nigeria.

The Protectorate of the Northern Nigeria went under series of amalgamation too before it was totally merged with the Southern Protectorate. The autonomous Emirate of Sokoto Caliphate, Sheikdom of Borno, the Igala and Jukun Kingdoms and numerous independents polities all became integrated by the British colonialists before the formal 1914 Southern and Northern Protectorate amalgamation.

\section{The essence of 1914 Amalgamation.}

In this section, the paper will start falsifying the perception and conception that the essence of 1914 amalgamation as well as the various amalgamations put in place by the British before 1914 were as a result of British desire to unite Nigeria which was originally before segregated and full of heterogeneity and antagonism.

This paper would like to establish that the above perception is false, the real essence or reasons for the 1914 amalgamation was economics (Mahadi et al, 1991) have established that. The British realized that the 
revenue generation for both the North and South was imbalanced in that the north proved to be landlocked and the south was not, so it boosted its revenue generation. (Falola, Mahadi, Anyanwu, Uhomoibhi, 1991)

In addition, for the British the amalgamation would coordinate development plans for the whole country (which was imbalance in terms of size and development). For instance there was the need to coordinate the railway policy or system. By 1914, three separate lines were in existence and a fourth line was being proposed.

Another factor that was a reason for the 1914 amalgamation was the relations between the administrative and political officers in the two protectorates there was much tension, due mainly to disagreements over policies and personality clashes between officers in the two Protectorates (Falola, Mahadi, Anyanwu, Uhomoibhi, 1991). Amalgamation became a very vital measure that the Bristish could undertake to reduce the tension that existed. These largely economic reasons were responsible for the British decision to amalgamate the Northern and Southern Protectorates of Nigeria in 1914.

\section{Chronologies Of Amalgamation}

As pointed out right from the introduction, the amalgamation of the North and South in 1914 did not happen haphazardly rather it was a gradual process that took place in each of the regions under the then colonial masters (East, west and North) this section will briefly look at the various stages of the amalgamation in the East, West, and the North.

\section{The Eastern Region}

The South Eastern part of Nigeria that we know today, has undergone several metamorphoses before and during the colonial period. The imposition of the British rule in Eastern province falls into two phases. The first phase stretched from 1849 to 1891. It was recorded that there was lack of law and order in the Eastern province before 1891 . This was as a result of their political structure. The Ibos, Ijo, Ibibio and the rest which were the predominant ethnic groups in the region were not centralized and they were egalitarian and fragmented. The British having subjugated the people of the East decided (without the consent of the people) to form Oil Rivers Province in 1891. This was done by the British to ensure effective control of the region and to maintain law and order (Siddique, 2009), and (Afigbo, 1980)

Military actions were taken against Afikpo and Umunneoha communities in 1903 then, the Akwete patrol and the grand Onitsha Hinterland Expedition in 1904. (Afigbo, 1980:413). In 1905 the Ezza, the Ororo, Nonya, Onicha and Ahiara communities were defeated. Two years later Isikwuabo, Urualla, Etche, Ntarakpu and Isiagu were fought and conquered. The years 1908, 1909, 1911, 1912 and 1914 saw scores of military units fighting and subduing various villages and settlements which still regarded themselves as independent of the British. (Afigbo, 1980:414)

Similarly, it is very vital to note that the communities in the Eastern province underwent series of transformation under the colonial rule. The various tribes and clans that existed in the region (as the case of other regions) were not in existence before as they are today, in other words they were not identified as they are today. For example the Aro, Ezza and other clans within the Igbo, never see themselves as Igbo. It was as a result of colonial contact that led to some transformations which led to the emergence of new clans and groups. The clans and tribal (Identities) we have today were the product of colonial contact as a result of economic, political and administrative styles. Siddique, 2009, Dunmoye, 2009, Paul, 2009, Afigbo, and Saad, 1980)

\section{The Western Province}

According to Otode (2003: 105) In the western region, two organized cultural areas were prominent, namely the Yoroba and the Edo. Neither of these groups, however, was entirely homogeneous. Among the Yoroba were groups with dialectical differences. In the Edo areas were groups who though linguistically mutually unintelligible were however closely connected culturally. There were groups like the Igbo, Ijaw Urhobo and Tsekiri who were basically non- Edo

To Asiwaju (1980) the events which culminated to the establishment of the British rule over the area under discussion resulted from the European imperial expansion in Africa which reached a climax in many places in the last quarter of the $19^{\text {th }}$ Century. With reference to the Western provinces of Nigeria the imposition of British rule was affected from two main bases: Lagos and the Niger Delta (Asiwaju, 1980:430).

It should be noted that Lagos was annexed in 1861 by the British and later the annexation was expanded to Badagry, Palma and Lekki [Adaribigbe cited in Asiaju 1980: 431] Gradually around 1891 there was an eventual declaration of a British Protectorate over Ilorin, Ado, Igbesa, Oke-odern and Ipokia by the British rulers through the acting Governor G-L Denten by 1897, the British Imposition reached Tsekiri Land which was achieved as a result of the removal of Nana Tsekiri and overthrow of Oba Overrawmen of Benin in 1894 and 1897 respectively. 
British rule began at different dates in different parts of the Nigerian territory west of the Niger. While a definite start was made in Lagos in 1862, Asiaju (1980), added that in the vast Yoruba interior the dates ranged from 1891 as in Ilaro and other related Western Yoruba towns to 1894 when Captain Bower appointed Resident over Ibadan in 1893. British sovereignty was extended in the second half of 1890 (Asiwaju, 1980).

\section{The Northern Province}

"The term Northern Province was coined by the British to describe the new entity they established by conquest at the beginning of this country" (Saad Abubakar 1980:447).

Before the British conquest, it should be known that there was no centralized authority (for the entire North of today) exercising political power over what became the Northern province, but greater part was under the Sokoto Caliphate (Saad, 1980:447) noted this. The beginning of the independence of various states and communities in the Northern States was in 1886 when the Royal Niger Company (RNC) attempted to consolidate its position through conquest to keep away other European rivals like France, Germany Belgium and Italy and to control the numerous communities of the region (Saad 1980:449)

Eventually, some of the Emirates and Chieftaincies were conqued by National African Company for example Buls and Chambal chieftaincies in 1885, Suntai Chieftaincy was also brought under control. By 1897 , Bida and Ilorin were conquered. Then not all the vast area of the North was under British control. The British then in 1897around September conquered Yola which constituted part of the upper Benue Province. In 1902, Zaria surrendered and Bauchi was occupied by the British, Later Borno accepted the British terms and finally in 1903, Kano was conquered while Katsina submitted peacefully and British finally confronted and defeated the Sokoto Caliphate.

\section{Amalgametion As A Means To An End}

As already acknowledged above, the primary aim of the amalgamation was the British economic benefit attached to it. In this section, the extent of the amalgamation and the means to its ends shall be looked into. Mahadi et al, (1991 P.7-8) maintained that even though Lugard was the Principal architect of the amalgamation, it was not necessarily his brainchild. Instead it was the brainchild of the British government. They contended that "amalgamation was not a moral issue." Amalgamation was not meant for the welfare of Nigerians. The concern was more on how the British would gain economically from it. The Amalgamations were not intended to help benefit Nigerians to come together as a unified or united nation (Falola, Mahadi, Anyanwu, Uhomoibhi, 1991), Dunmoye, (2009), Afigbo (2003), Sa'ad (2003) and Tanimu (undated) acknowledge this.

Another factor that proves the amalgamation pseudo was the fact that despite the amalgamation of 1914, which brought the North and South together. Full powers were exercised by the Governor General, Lord Lugard and his successors and the Lieutenant Governors who were appointed separately for the North and South respectively. Lagos remained a Colony and its citizens were given rights as British Citizens. People in the rest of Nigeria were called "protected persons". (Falola, Mahadi, Anyanwu, Uhomoibhi, 1991)

Furthermore, despite the amalgamation policy not all of the departments were amalgamated, a centralized government where North, South, and the Colony of Lagos would work together was missing. Lugard continued to decentralize his government by resolving to maintain the differences in the administration of the North and South. Departments like Police and Prisons were not amalgamated until 1970 while, Treasury, Railways, Surveys, Post and Telegraph and Audit were amalgamated later.

Another failure of the amalgamation was that the North was left unsplited (intact) while the South was broken into nine (9) Provinces each headed by a Colonial Officer. This shows that the essence of the amalgamation was not to unify the country but instead for economic and administrative reasons.

This conclusion was confirmed by Afigbo, $(2003 ; 49)$ when he said, 'The political, the economic, the cultural, the religious, the linguistics and all the rest It was perhaps only from the days of Sir Hugh Clifford as Governor that the baggage of amalgamation in Nigeria came to be consciously recognized as including political amalgamation'. This quotation was also confirmed by (Perherm,1960) thus, "His (Luggard) task, it must be repeated, was to unify administrations not people". In reality, amalgamation was and has remained a humdrum rather than a grandiose process of bringing the diverse people of the Niger Benue areas together not for the purpose of creating a smooth amalgam of one people and one culture but for the purpose of enhanced ease, harmony and satisfaction in the management of their common interests, and thus reducing tension and acrimony in their inter-group relations. It was not and is not a one short affair, nor was it a politico-administrative project nor did it start with British colonial rule. It was always been a "multi-faceted project" (Afigbo, 2003; 51). 


\section{Conclusion}

From the analysis pointed above we should understand the British style of conquering Nigeria was to deal with the periphery before the center as demonstrated in their methods of regional control before the final amalgamation of the Southern and Northern Protectorate in 1914. Nigeria came into being after series of amalgamations and transformations. The prime aim of the 1914 amalgamation was economic interest and to ease British control of the entire Nigeria not for unification. The Amalgamation of 1914 was not meant to benefit the people of Nigeria but rather to unite the various ethnic groups together for smooth and effective control of the country by the British.

\section{References}

[1]. Abubakar Saad (1980) 'The Northern Provinces Under Colonial Rule 1900-1959.'Ground Work of Nigerian History. Historical Society of Nigeria

[2]. Afigbo, A.E (2003) 'The Eastern Province under Colonial Rule'.Ground Work of Nigerian History; Published by Historical Society of Nigeria

[3]. Asiwaju, A.I (1980) 'The Western Provinces Under Colonial Rule'

[4]. Ground Work of Nigerian History. Historical Society of Nigeria

[5]. Bala, Y.B, Alkassim A (1991) Misrepresentation of Nigeria: The Facts And the Figures. Center for Development and Research Training; Zaria

[6]. Dunmoye R. A (2009) MSc Lecture Notes. Department of Political Science, Ahmadu Bello University, Zaria, Nigeria

[7]. Falola T, Mahadi A, Uhomoibhi M, and U Anyanwu (1991) History of Nigeria 3: Nigeria in the Twentieth Century. Ilorin; Longman Nigeria PLC

[8]. Kirk-Greene A. H. M (1996) Luggard and the Amalgamation of Nigeria: A Documentary Record: FRANCASS \& CO LTD

[9]. Obaro Ikeme (1980) (ed) Ground Work of Nigerian History. Heinemann Publishers

[10]. Olaniyan R. A (2003) The Amalgamations and Its Enemies: An Interpretive History of Modern Nigeria. Ibadan OAU Press, Ltd

[11]. Otoide L . E (2003) 'Renegotiating Political Space: Minorities, Border disputes and Inter communal Clashes.'The Amalgamations and its enemies: An Interpretive History of Modern Nigeria. OAU Press LTD

[12]. Perharm, M (1960) Lugard: The years of Authority 1898 1914; London

[13]. Siddique A (2009) MSc Lecture notes. Department of Political Science, Ahmadu Bello University, Zaria, Nigeria.

[14]. Tamunu. T. N (undated) 'British Colonial Administration in Nigeria in the Twentieth Century 'Ground Work of Nigerian History. Historical Society of Nigeria 